водство и развитие общества. Кроме того, социальная коммуникация предстает не только как средство и критерий развития культуры, но и как цель ее развития - как в очевидном случае коммуникативной культуры, так и в более широком смысле любой коммуникации как культуры. Если в первом, узком, смысле идет речь о чем-то по значению близком к этикету, то во втором, широком, смысле, который задает ценностно-смысловой горизонт для понимания всей культуры, последняя выступает как коммуникация - актуальная и потенциальная.

Ключевые слова: культура, коммуникация, социальная коммуникация, ценности, социальные функции, социальные роли, социальная технология.

M. I. Boychenko, Doctor of Philosophical Science, Professor,

Taras Shevchenko National University of Kyiv

60, Volodymyrska Street, Kyiv, 01033, Ukraine

\title{
COMMUNICATIVE PARADIGM OR CULTURAL RESEARCH
}

In the article the culture is considered from the perspective of the priority of its communicative dimension. Social communication emerges as the basis for the creation and reproduction of culture as one of the important means and to some extent the ultimate goal of cultural development. The grounded thesis is that satisfactory consideration of the functioning of culture in a society is impossible without taking into account communicative mechanisms of its provision. It reveals the leading role of values in determining the communication as a functional basis of culture: the values of culture, acquiring functional social purpose (in particular, in the form of social roles), ensure the participation of society members in both social life in general and in its development by means of culture. The communicative criterion makes possible to define as culture only that things made by a person, which promote social communication, that is, that ensure the reproduction and development of society. In addition, social communication is not only a means and a criterion for the development of culture, but also should be considered as a goal of its development - both in the obvious case of communicative culture and in the broader sense of the culture of any communication. In the first, narrow sense we are talking about is close in importance to etiquette.In the second, broad sense which sets the value-semantic horizon for understanding the culture in general, the latter appears as a communication - actual and potential.

To determine the systemic dimensions of the culture functioning one should determine the levels of implementation of social communication in society. After all, culture is the product of human communication, and it is also the cause and the foundation - even when it comes to personal culture (since everything done by a person needs to be checked and reinforced or denied by others). In general, it is worth to think about building a communicative concept of culture, which would proceed from the idea of an intersubjective essence of a human as a social being.

The following levels should be distinguished, from the lowest to the highest: direct interaction, interaction within organizations and communities, cooperation within countries as complex territorial associations of communities, interaction within the framework of a global society as a super-"community". At each of these levels, there are varieties of values that attract individuals to engage in communication at the appropriate level. In turn, these values determine certain social roles and functional queries that are distributed or grouped around these social roles. The fulfillment of social roles forms the basis of the culture of social communication, that is more or less developed. Performing roles is concentrated in the personal culture of communication only at first glance - both skill and persuasiveness and successful performance. In addition to the personal culture of communication participation, the collective communication culture should be distinguished, most of which consists in those unwritten rules of conduct that, without special arrangements and even without articulation, are implicit, but certainly perceived by the communicative community as the basis for a successful social life. The higher the level of social communication, the greater the success of social interaction depends on the reinforcement of unwritten rules of conduct rationalized norms. Universalist norms represent the means of guaranteeing mutual understanding at the highest levels of social communication.

In order to treat culture as a certain ideal and as the embodiment of higher values, which we can and should endlessly seek and approach, we must first (in the mode of pre-understanding) comprehend culture as the external side of our experience, as that which in general enables any our act and aspiration. Such an interconnection of the beginning and end, goals and means can be gained through the study of social communication and at each of the aforementioned level, this connection is specific. However, each time it is a connection between certain values that define the goals, and certain functions that determine the means of communication.

We should strive to establish the definition of the concept of values interconnected with the definition of the culture notion. Valuable analysis of this is, at the same time, an analysis of values as a subject of research, and an analysis from the standpoint of values, that is, values should serve as the basis of our methodology. Since it is a question of human knowledge of human activity, there is no contradiction here, but there is a performative statement of the methodology of the study, its formation under the influence of an even deeper immersion in the subject of knowledge. This means that the methodology should come from our way of life, and not be reaffirmed by the backwards of some forced indents and compromises with our way of life.

Key words:culture, communication, social communication, values, social functions, social roles, social technology.

Удк 2.17.2-42.17

І. В. Кондратьєва, д-р філос. наук, доц. Київський національний університет імені Тараса Шевченка вул. Володимирська, 60, м. Київ, 01033, Україна iryna.k@i.ua

\section{ІДЕЙНІ ВИТОКИ ЕТИЧНОї ДОКТРИНИ КИЇвСЬКИХ АКАДЕМІСТІВ}

У статті здійснено аналіз витоків етичної доктрини київських академістів другої половини XIX - початку XX ст. Актуальність теми зумовлена необхідністю осягнути етичну наповненість духовно-академічного філософування Київської школи, внести певні корективи в методологію вітчизняних історико-філософських досліджень. Етична наповненість реліеійно-моральнісних пошуків київських академістів полягала у своєрідному баченні та витлумаченні проблем чеснот, обов'язку та ідеї блага. Ідейними витоками етичних ідей мислителів Київської духовної академії є твори отців церкви у візантійській інтерпретації, з одного боку, а з другого - моральна філософія Канта, Фіхте та деяких інших німецьких філософрів етичного ґатунку.

Ключові слова: теїстична етика, моральна філософія, моральність, богословські чесноти, моральнісний ідеал, благо.

Постановка проблеми. За умов реалій сьогодення, коли в духовному кліматі суспільства зійшлись воєдино песимізм і оптимізм, квієтизм і нігілізм, коли свобода вибору людиною світоглядних орієнтирів зрештою вийшла за рамки лише можливостей, особливо актуальною постає потреба в адекватних моральнісних цінностях. Важливо нині також з'ясувати те, наскільки дієвим, змістовно привабливим і придатним для практичної реалізації виглядає християнське вчення про мораль, зокрема в тому його варіанті, який свого часу був запропонований київськими академістами, та визначити те, чи взагалі християнська мораль $є$ відповідальною за осмисленість життя людини. Теоретично обґрунтовану відповідь на питання такого ґатунку можна знайти у творчому доробку представників духовно-академічної думки. У цьому виявляється актуальність звернення до висунутих та з'ясованих академістами питань етичного змісту.
Аналіз досліджень і публікацій. Спадщина київських академістів другої половини XIX - початку XX століття поставала предметом дослідження дореволюційних істориків фрілософії Е. Гайдадима, В. Зеньковського, Е. Радлова, Г. Шпета, які здійснили джерелознавчий аналіз творчості деяких київських академістів, що стало першим досвідом фрілософського розгляду київської духовно-академічної традиції.

Вітчизняні дослідження звернені як до окремих персоналій, так і до київської духовно-академічної традиції фрілософування в цілому. Так, творчий доробок київських академістів розглядали та аналізували А. Апанасенко, А. Арістова, А. Баханов, Ю. Кравченко, С. Кузьміна, М. Лук, В. Нападиста, Н. Мозгова, А. Панченко, Л. Пастушенко, І. Печеранський, Л. Раба данова, О. Сарапін, М. Ткачук, І. Фицик, Г. Христокін, І. Юрас та ін.

( Кондратьєва І. В. 
Мета статті. На підставі аналізу визначальних ідей і концептів християнського релігійно-моральнісного вчення академістів розкрити сутність та зміст феномена теїстичної етики Київської школи.

Виклад основного матеріалу дослідження. Характерною рисою духовно-академічної фрілософії другої половини XIX - початку XX ст. була ії виразна етична націленість. Відповідно, релігійно-філософські концепції київських академістів відзначались своєю належною етичною наповненістю, розгорнутими постановками і розв'язанням проблем моральнісного ґатунку.

Звісно, що етичну зорієнтованість можна вважати характерною рисою вітчизняного стилю фрілософування, невід'ємною складовою якого була й духовно-академічна думка, хоча б з огляду на її прикметну належність саме до православної традиції. Однак не варто обмежуватись констатацією виразного релігійно-етичного лейтмотиву, властивого духовно-академічній думці. Доцільно торкнутись в зв'язку з цим саме причин наголошування київськими мислителями в своїх творчих розвідках на етичній проблематиці. Такими причинами слід визначити: 1) необхідність виправдання академістами в світлі моральних постулатів своїх метафізичних, гносеологічних, а подекуди й есхатологічних розробок; 2) актуалізовану тенденцію до етизації фрілософських концепцій (не без впливу Канта), яка була характерною для розвитку європейської думки другої половини XIX ст.; 3) потреби соціальної практики, викликані пошуками альтернатив виходу із світоглядної кризи внаслідок ціннісних зрушень у суспільстві напередодні революційних змін - з одного боку, з іншого - небажаними явищами соціального ґатунку; 4) розповсюдження в тодішньому суспільстві нігілістичних ідей, які призводили до занедбаності моральнісних орієнтирів.

Вищезазначені причини були зовнішніми чинниками формування етичної доктрини академістів. Однак доволі істотними видаються і внутрішні, ідейні стимули появи феномена "теїстичної етики". Під поняттям "теїстична етика" розуміємо змістовно цілісні, належним чином концептуально оформлені результати релігійно-моральнісних пошуків академістів. Поява феномена теїстичної етики викликана була: а) переважно, але не винятково впливом східновізантійської традиції, що була логічним продовженням святоотчих вчень; б) впливами моральної фрілософрії Канта й почасти Фіхте та теїстично зорієнтованих теорій німецьких мислителів XIX сторіччя.

Тому постає потреба розв'язання проблеми витоків ідей київських академістів. Але спочатку варто з'ясувати, наскільки в змістовному відношенні впливовою щодо формування етичної доктрини академістів виявилась святоотча традиція в її морально-повчальному вимірі.

У цьому відношенні однією з найбільш впливових виявилась для академістів аскетична течія східної патристики. Серед провідників аскетичного ідеалу своїми морально-повчальними розвідками виділяється Афанасій Александрійський, прозваний Великим. Мораль Афранасій зводив до обов'язків. При цьому обов'язком християнина проголошувалась невинність, непорочність. Виходить, що моральність у Афанасія обмежується подоланням чогось, пов'язаного з почуттєвістю.

Крім того, з іменем Афранасія Александрійського пов'язують розкриття започаткованої Іринеєм Ліонським ідеї обоження, що стала в подальшому однією з визначальних ідей у контексті православного світосприйняття. Афанасій тлумачив обоження як єднання з Богом, уподібнення Його властивостям. Це уподібнення цілком можливе й шляхом моральнісного удосконалення людини, шляхом поступового набування нею тих чеснот, які в абсолютному ступені приписуються Богу. До речі, в такому тлумаченні виявляється виразний етичний аспект концепції обоження.
Про аскетизм і християнську досконалість багато писав у свій час Макарій Єгипетський, якому приписують авторство біля п'ятдесяти бесід (так званих духовних гомілій) морально-повчального характеру. I знову ті ж рекомендації: як людині стати над почуттєвістю, позбавити себе усіляких зв'язків з нею. По мірі долання почуттєвості, вважає Макарій, людина наближається до Бога. У духовних гоміліях також йдеться про обов'язковість дотримування людиною заповідей Божих та про можливість набування нею чеснот. При цьому чесноти мають сенс лише в контексті стосунків людини з Богом, точніше на шляху смиренного відношення людини до Бога.

3-поміж сентенцій аскетів дещо вирізнялись положення морально-повчального характеру сірійського отця церкви Іакова Афраата. На думку о. Іакова, засада віри - Ісус Христос. Людина насамперед вірує; після того як увірує, вона любить; після того як полюбить сподівається; після того як проникнеться надією - виправдовується; і зрештою, після того як виправдовується - стає досконалою. У вищенаведеній сентенції можна вбачати своєрідну спробу з боку Іакова Афраата окреслити дії так званих богословських чеснот. Це та спроба, що в подальшому була актуалізована в етиці профресора КДА Маркеліна Олесницького.

3 аскетичних за змістом творінь популярними серед академістів були численні переклади проповідей і листів Григорія Богослова. Зокрема, його вчення про євангельські поради і про їх відмінність від загальнообов'язкових моральнісних законів суттєво вплинуло на розробку академістами проблем, що стосуються етики обов'язку. Крім того, темою свого відомого "Слова 14" Григорій Богослов обрав головні богословські чесноти: віру, надію, любов - ті чесноти, що стануть предметом докладного аналізу духовних філософрів.

Окремо варто сказати про морально-повчальні творіння св. Іоанна Златоуста та його тези про чернецтво як справжню філософію, про невинність як ангельський стан тощо. Однак Іоанн Златоуст не обмежувався описом споглядального життя аскета. Натомість він багато писав про "життя діяльнісне". До речі, царицею з-поміж чеснот Златоуст вважав милосердя. Крім того, о. Іоанн особливо наголошував на тому, що засада, початок і сутність всієї моральності - любов до Бога. Відповідно, людина в своїй діяльності повинна керуватись цією максимою.

Зрештою, особливим попитом у академістів користувалась своєрідна хрестоматія морально-повчального характеру, відома в християнському світі під назвою "Ліствиця, що зводить на небо". Її автор - відомий отець-аскет, чудотворець, ігумен Сінайської гори Іоанн Ліствичник. Його творіння $€$ духовною скарбницею святоотчої літератури, в якій описується здіймання "від земного до святая святих, на вершині якої утверджується Бог любові". Київських академістів ця збірка приваблювала описами різноманітних внутрішніх станів людини, її чеснот i, насамперед, настановами, порадами тощо. Показовим видається поданий І. Ліствичником саме психологічний аналіз суб'єктивних станів і порухів людини, втім здебільшого тих станів, що мають мало спільного з християнською мораллю. Загалом, за влучним зауваженням О. Гренкова, "вся аскетична література була не стільки з'ясуванням позитивного ідеалу, скільки саме негативним аналізом того, що є нехристиянського в людині. Того, що належить до сфери гріха" [4, с. 365]

3-поміж ідейних впливів з боку західних отців церкви доволі відчутним виявився вплив на духовних філософрів вчення про моральність Амвросія Медіоланського. Його відомий твір "Про обов'язки священнослужителів" більшість дослідників вважають першою спробою викладу християнської моральності. Більш того, це був "перший досвід явити християнську мораль в її відмежованості від віровчення" [1, с. 19]. У своєму творі, викладеному за за- 
гальною схемою подання матеріалу Цицероном, Амвросій Медіоланський докладно з'ясовує моральнісні обов'язки спочатку кліриків, потім - всіх християн. До речі, виразний вплив етики Цицерона позначився на розгляді автором вчення про чесноти. Зокрема, Амвросій Медіоланський за основу бере чотири головні чесноти: мудрість, або розсудливість (prudentia); справедливість (justitia); мужність (fortitudo) та поміркованість (temperantia). Наповнюючи їх християнським смислом, він у мудрості вбачає відношення людини до Бога, в справедливості - відношення людини до ближніх, у мужності - відношення людини до обставин життя, й зрештою поміркованість він тлумачить як відношення людини до себе. Далі, остаточною метою людини в цьому світі Амвросій проголошує богоуподібнення (приймається як summum bonum). Звідси - обов'язок людини полягає в прагненні до досконалості, у сповненні моральнісного ідеалу. При цьому на шляху здійснення цього моральнісного ідеалу людина або обмежується виконанням лише заповідей Божих, або виконує поради євангельські.

Своєрідним показником насиченості патристичних настанов, морально-повчальних сентенцій у духовноакадемічній стихії можуть служити неодноразові переклади відомої аскетичної хрестоматії "Добротолюбіє". До цієї хрестоматії ввійшли ті витяги із творінь представників святоотчої писемності, які відзначались яскраво вираженою моралізаторською спрямованістю.

У цілому завдяки святоотчим морально-повчальним творінням для академістів, словами О. Бронзова, "з'явилась можливість правильніше розуміти висвітлені в останніх (святоотчих творіннях. - І.К.) євангельські принципи моральності" [2, с. 562]. Якщо ж спробувати знайти визначальну рису у всіх уявленнях та ідеях моральнісного ґатунку, що містились в творіннях святих отців та вчителів церкви, то такою рисою слід визнати домінування так званої етики чеснот. Іншими словами, опис чеснот до надмірної психологізації був вкрай характерним для численних патристичних викладів. Саме особливості такого опису відлунням викарбувались у моральнісних розвідках академістів, особливо виявляючись у Назарія Фаворова.

У світлі пошуку патристичних впливів цікавим видається порівняння особливостей викладу проблем етичного ґатунку академістами і їх попередниками - викладачами КиєвоМогилянської академії. Ґрунтуючись на висновках з праць вітчизняних дослідників В. Нічик та М. Кашуби, можна стверджувати про виразне арістотелівське розуміння етики, властиве київським профресорам XVII - першої половини XVIII ст. Відповідно, ця наука у філософських курсах Г. Кониського, М. Козачинського, Ф. Прокоповича та інших мислителів постає як вчення про мораль, отже, про набування людиною в процесі виховання діяльнісно-вольових та душевних якостей. До цього ж М. Кашуба стверджує, що етика в Україні XVII - першої половини XVIII ст. розвивалась за двома головними напрямками, що, в свою чергу, мали наслідком, з одного боку - оформлення теоретичної, споглядальної науки моральності (І. Вишенський, С. Калиновський), з іншого появу натуралістичної етики, що містила ідеї утилітаризму і евдемонізму (братчики, К. Ставровецький, І. Гізель, Сильвестр Кулябка, М. Козачинський, Г. Кониський).

Однак, незважаючи на відмінні засадничі моральнісні установки, в цих етиках (споглядальній та натуралістичній) розкриття окремих питань було продиктоване домінуючим арістотелівським підходом. Вельми показовим в цьому відношенні був лекційний курс Феофілакта Лопатинського "Scientia sacra" (1706-1710), укладений в цілковитій узгодженості з системою Фоми Аквінського. Свідчення про цей курс подає Г. Флоровський [14, с. 98]

Натомість київські духовні фрілософи в своїх релігійно-моральнісних розвідках відштовхувались від святоотчих уявлень про мораль, які подавались у виразному платонівському забарвленні.
Якщо святоотча ідейна спадщина виявилась своєрідним постачальником морально-повчального матеріалу для етичних розвідок академістів, то концептуальному оформленню їх доктрини сприяв вплив німецької практичної фрілософії, й зокрема вплив кантіанської фрілософрії. Упродовж XIX ст. серед мислителів духовних академій ніколи не згасала зацікавленість німецьким ідеалізмом. Г. Флоровський в своєму капітальному дослідженні писав навіть про "зачарованість німецькою філософією в середовищі академістів" [14, с. 492]. При цьому визначальним для оформлення теїстичної етики академістів виявився вплив ідей кантіанської моральної фрілософіії.

Причинами кантіанського впливу були: 1) розробка і використання Кантом категоріальної мови для вираження загальнолюдських норм, заборон і цінностей; 2) властива етичній концепції Канта апріорність з усіма її наслідками; 3) яскраво виражена антикатолицька спрямованість моральної проблематики кенігсберзького мислителя; 4) неспроможність гегелівського панлогізму осмислити царину моралі (у тодішньому суспільстві десь з 70-х років виразно відчувалась криза гегелівської філософії і повернення до філософії Канта).

Розглянемо не лише констатацію цих причин, а детально їх з'ясуємо. Спочатку що стосується розробки Кантом категоріальної мови для вираження явищ морального ґатунку. Доцільним $є$ виділення в змісті практичної філоcoфpiï Канта двох складових: безпосередньо його етики i моралістики. До змісту етики Канта входять його тлумачення природи моралі; розкриття феномена людської волі; вчення про категоричний імператив й, відповідно, випливаючи з цього вчення, антиномізм гіпотетичного і категоричного імперативів; критика емпіричних теорій моралі тощо. Головні проблеми його етики висвітлюються переважно в відомій "Критиці практичного розуму" [9]. Ґрунтовний аналіз кантівської етики пропонує О. Дробницький в своїй праці "Поняття моралі" [5, с. 64-77].

3 іншого боку, до моралістики Канта відноситься вчення про чесноти з огляду на їх описові характеристики. Яскравим свідченням моралістики Канта служать його "Лекції з етики", читані фрілософом у Кенігсберзькому університеті в 1780-1782 роках [див. 8]. Саме в його "Лекціях з етики" містяться емоційно наповнені визначення людських якостей і обов'язків. Відразу ж варто зауважити, що моралістика Канта залишилась поза увагою київських академістів, принаймні в своїх творах вони не подають розуміння Кантом людських якостей.

Привабливим для академістів стає кантівський підхід до етики як "критики феноменології моральної свідомості" з відповідним набуванням дисципліною самостійного статусу та визнанням абсолютності моральних вимог. Зокрема, новий кантівський підхід до етики багато в чому сприяв процесу остаточного офрормлення автономності теїстичної етики академістів у формі чи "морального богослов'я", чи "моральної фрілософії" й навіть привів до домінування в їхніх релігійних пошуках етичної проблематики. У зв'язку з цим професор КДА Маркелін Олесницький писав, що "'кантівська автономія" спричинила те, що моральне богослов'я виграло перше місце в порівнянні з догматикою" [12, с. 201].

3 іншого боку, новий підхід в етиці мав наслідком апологію зобов'язаності, що знайшла відображення в проголошеному Кантом постулаті категоричного імперативу. Суть цього категоричного імперативу: "чини тільки згідно такої максими, керуючись якою ти водночас можеш побажати, щоб вона стала всезагальним законом" [9, с. 260]. У свою чергу ця зобов'язаність $з$ іï визначальним принципом "повинен" ставила хрест на аргументації про наявність в природі людини природжених почуттів як начал моральності, і взагалі вона спростовувала тотожність моралі і людської афектив- 
ності. До речі, О. Дробницький слушно вбачав в цьому "деякий християнський умонастрій Канта: мотиви "приборкування гордині”, визнання людиною своєї недосконалості і самообмеження, що висуваються ним як методологічний принцип" [5, с. 66]. Натомість Кант намагається знайти те, що "возвеличує людину над нею самою як часткою чуттєво сприйманого світу" [9, с. 413]. Саме всезагальність категоричного імперативу стає на заваді не лише "приборкуванню гордині" людини, але й вияву ї̈ егоцентричних схильностей. Влучно підмітив сучасний німецький філософ Ю. Габермас, що "категоричний імператив вперше пориває 3 егоцентризмом Золотого правила... визнаючи максиму справедливою лише тоді, коли всі можуть бажати, щоб кожен слідував їй в аналогічних ситуаціях" [15, с. 16].

Притаманна кантівській етиці апріорність була зручною для академістів. Головне - апріорним у Канта проголошувався категоричний імператив, тобто основний моральний закон. Цей моральнісний закон має ознаки всезагальності, необхідності та фоормальності. Іншими словами, він не виводиться $з$ досвіду, взагалі з емпіричних фактів цього світу, а тому має безумовний характер. У свою чергу, безумовність моральнісного закону викликала як неодмінні умови - необхідність свободи волі, визнання безсмертя душі і існування Бога. При цьому категоричний імператив, цей інструмент практичного розуму, не доводить їх істинність, оскільки це не його компетенція. Словами Канта: "всезагальність максими як закону, отже, моральність нам, людям, звісно що не під силу" [9, с. 307]. Натомість категоричний імператив постулює наявність свободи волі, безсмертя душі i, що важливо для академістів, проголошує постулатом існування Бога.

Антикатолицька спрямованість етичної доктрини Канта теж зіграла свою роль у справі осмисленого сприйняття її академістами. За образним виразом О. Гренкова, "вся німецька фрілософрія (не лише Канта. - І.К.) була істинною дочкою німецького протестантизму". [3, с. 12]. Завдяки протестантському кругозору Кант проголошував зайвими, непотрібними казуїстичні нагромадження католицьких за духом етик, відкидав їх логічно витриману, систематизовану "сітку" чеснот. Однак наслідком протестантського кругозору була універсальність, що, в свою чергу, приховувала в собі й небезпеку для православно зорієнтованих концепцій академістів. Идеться про те, що універсальність зводила нанівець всю об'єктивну сторону релігії. Отже, виходить, все, що Бог здійснює для людини і її спасіння, в світлі протестантизму відкидалось як трансцендентне. Натомість універсальність стверджувала цілковиту суб'єктивність.

Що ж стосується запропонованої Гегелем системи моралі, варто визнати ї̈ банкрутство в середовищі академістів, навіть серед тих, хто співчував його метафізиці чи методу. Визначальною рисою гегелівської етичної доктрини була декларована нею відносність виявів моральності, оскільки статусом абсолютності володіє лише знання. Як наслідок, позбавлення моралі ї̈ абсолютного характеру загрожувало її божественності. Іншими словами, принцип відносності моралі приводив до заперечення ії божественності. Не дивно, що в своїх релігійно-моральнісних пошуках жоден з київських академістів не звертається до етики Гегеля.

Варто зазначити також, що духовні фрілософи в своєму осмисленні етикотеології Канта керувались загальним критичним підходом. Вони добре розуміли слабкі аспекти моральної доктрини Канта, а саме: її формалізм, підпорядкованість релігії моралі тощо. Особливо неприйнятним для київських професорів було зближення кантівської моралі з цариною права. Зокрема, професор КДА Маркелін Олесницький писав, що "Кант виводить поняття моральності з відносин людини до інших людей і тому змішує моральність з громадянським правом" [12, с. 179].
Етика Фіхте загалом сприймалась академістами як крайній вияв кантівської системи моралі, як її логічне продовження. Щоправда, і це важливо відзначити, не етичні конструкції Фіхте приваблювали академістів, а їх моралізаторське доповнення. Йдеться зокрема про патетичний виклад Фіхте тези про єднання людської природи і божественної (до догмату про олюднення філософ виявляв особливу прихильність) і також про своєрідний гімн любові, що дуже нагадував величну проповідь любові апостолом Іоанном.

Потужний вплив кантівської практичної фрілософії викликав до життя безліч теїстично орієнтованих етичних доктрин німецьких мислителів-богословів. При цьому не завжди ці мислителі дотримувались в своїх висновках проголошених Кантом принципів філософії. Більшість 3 них вдались до розробки окремих аспектів кантівської системи моралі, тих аспектів, які потім знайшли втілення і в етичній доктрині київських академістів. Тому доцільним видається торкнутися головних положень етичних концепцій найбільш впливових німецьких теїстів.

Богослов М. Ястребов в своїй ґрунтовній праці "Нова точка зору в системі моральнісного богослов'я"[16] неодноразово натякнув на згубний річлівський вплив на систему моралі, запропоновану Маркеліном Олесницьким. В чому ж він виявляється? Щоб відповісти на це питання, достатньо буде з'ясувати визначальні положення етики німецького теїста, свого часу професора Геттінгенського університету Альберта Річля.

В основі його етики - поняття любові як виняткової властивості Бога. У світлі цього поняття зневільовуються всі предикати Бога, як-от святість, всемогутність, всеблагість і т. п. Як наслідок абсолютизації любові - у А. Річля з'являються мотиви заперечення гніву Божого як пояснення первородного гріха, страждання і смерті Ісуса Христа тощо, більш того - богословом декларується заперечення первородного гріха як такого. При цьому власне любов він тлумачить як "волю, що, переконавшись в значимості якогось певного об'єкта, намагається засвоїти цей об'єкт собі або забезпечити йому поступовий розвиток..." [цит. за: 16, с. 375].

Безпосереднім предметом божественної любові з моменту творення світу є заснування в межах емпірії чогось подібного до релігійної спільноти моральнісних істот, тобто актуалізація "моральнісного ідеалу". Відповідно, вищою метою світу людини і самого Бога А. Річлем проголошується "моральнісний ідеал", до якого можна наблизитись, лише діючи в цілковитій узгодженості із законами любові. При цьому свобода людини - лише первісна "діяльнісна" ознака "моральнісного ідеалу".

Запропонована А. Річлем система моралі $є$ варіантом "етики блага", тієї етики, прихильниками якої стануть київські академісти. Більш того, Маркелін Олесницький в основу своєї системи християнської моралі покладе ідею "царства Божого" - своєрідного еквівалента "моральнісного ідеалу". У свою чергу, визначальною характеристикою "царства Божого" буде ідея любові.

Значного впливу зазнали київські академісти з боку відомого німецького богослова і фрілософа Фрідріха Шлейєрмахера. Для ознайомлення з його етичною доктриною велике значення має праця "Критичний огляд досьогоднішньої моральності" (свідчення про цю книгу подає О. Гренков) [див.: 3]. У цій праці Ф. Шлейєрмахер стверджує, що етика повинна займатися аналізом ідеї вищого блага. Відповідно, саме такий аналіз забезпечить їй право на статус науки й уможливить її подальший розвиток. Звідси, сенс релігійності, за Ф.Шлейєрмахером, полягає в здійманні від кінцевого людського до вічного, божественного, а значить в осягненні безсмертя. Відповідно, бути релігійним означає не що інше, як знаходити в собі одкровення Боже. При цьому підкреслимо, що релігія i, в остаточному підсумку, мораль розпочинаються з суб'єктивної діяльності. Ця діяльність лю- 
дини виявляється навіть у будь-якому її впливі на природу. Однак Ф. Шлейєрмахер у своїх розвідках допускає маніхейський дуалізм, приписуючи духу, або розумові, добро, а природі, або матерії, - зло. За такий дуалізм його піддає нищівній критиці Маркелін Олесницький [див.: 12, с. 179-181]. Знову-таки, на перший план Ф. Шлейєрмахер, як і А. Річль, висуває "етику блага", не ігноруючи, однак, кантівську "етику обов'язку". У цьому відношенні Ф. Шлейєрмахер постулює навіть всезагальний закон обов'язку, згідно з яким людина повинна діяти в кожну мить, зібравши всі свої моральнісні сили, і прагнути при цьому до всіх моральнісних цілей. До речі, Ф. Шлейєрмахер у своїй моральній доктрині подає поділ етики в структурному відношенні на вчення про благо, вчення про чесноти і вчення про обов'язки. У подальшому подібна структурованість виявляється в етичних концепціях київських академістів.

Загалом значення вчення про мораль Ф. Шлейєрмахера в історії етики досить влучно показав саме професор Маркелін Олесницький. На його думку, "він (Шлейєрмахер. - І.К.) звільнив моральне вчення від кантівського догматизму і на місце беззаперечного "повинно" поставив вільне "потрібно". Він вказав на серце як на джерело добра і зла; він припускав, що самосвідомість християнина, так би мовити, налаштована по-християнськи; він дивився на моральну діяльність кожного індивідуума як на процес творчий, оригінальний, а не як на копію лише закону (як виходить у Канта)" [12, с. 201-202].

Ганс Лассен Мартенсен, датський теолог-протестант, був відомим на той час як автор капітального дослідження "Християнське вчення про моральність" [63]. У цій праці він подає виклад християнської моральності, послідовно розгортаючи його в богословському, космологічному, сотеріологічному й есхатологічному аспектах. Досить ретельно i, що важливо, систематично розглядає він основні поняття моралі. Основними предметами етики Г. Мартенсен вважає закон, чесноти і вище благо. До речі, на думку Г. Мартенсена, "етика своїм завданням має складний і заплутаний лабіринт людських дій, розглянутих в їх відношенні до одкровення і до віри" [11, с.67]. Відповідно, богослов починає свою етику з опису "індивідуального життя людини під законом і гріхом" і ...завершує актуалізацією царства Божого шляхом оновлення в спокутуванні. Безумовно, що система моралі, запропонована Г. Мартенсеном, була впливовою в колі духовних фрілософів. Особливо популярними були виклади окремих питань етичного ґатунку, щоправда, академісти їх пропускали крізь призму конфесійної упередженості.

Певний вплив на академістів мав і німецький протестантський богослов Адольф Вуттке, який у своїй праці "Підручник з християнської моральності" значну увагу приділяв з'ясуванню сутності морального богослов'я, його специфріці та розмежовуванню 3 фрілософьською етикою. У доволі розлогому вступі (318 сторінок) А. Вуттке подає навіть "історію морального вчення і моральної свідомості взагалі". Запропоноване ним вчення про мораль включає три частини, з яких у першій йдеться про "моральне саме по собі, безвідносно до гріха", в другій - "про спотворення морального в площині гріха" й, зрештою, в третій - "про моральнісне життя в його оновленні через спокутування" [див.: 18]. Що ж до особливостей викладу етичної доктрини, А. Вуттке багато в чому дотримується логіки викладу питань Г. Мартенсеном. Цікаво, що київські академісти в своїх працях багато посилаються саме на А. Вуттке.

Лютеранський теолог, послідовник Ф. Шлейєрмахера Ріхард Роте в свій час уславився як "апостол спекулятивного богослов'я" [21, с. 226]. Для з'ясування головних положень етичної доктрини вельми показовою є його трьохтомна праця "Теологічна етика" [114]. У цій праці Р. Роте власне мораль разом з фрізикою включає до царини космології як необхідної складової так званої спекулятивної теології. Відповідно, моральність тлумачиться ним як продовження творчого акту вже з боку людини. Іншими словами, саме завдяки моральності людина стає співробітником Божим в процесі світотворення. Етику, в свою чергу, Р. Роте визначає як науку про власне самовизначення людини і як науку про все, що ґрунтується на цьому самовизначенні. Серед окремих аспектів його етичної доктрини київські академісти не сприйняли його вчення про гріх як необхідну стадію моральнісного процесу, стадію, через яку обов'язково повинне пройти людство. Логіка викладу етики Р. Роте подібна до логіки викладу етичної доктрини Ф. Шлейєрмахером, однак поступається останній в послідовності та ясності понятійного вираження.

3 іншого боку, доволі впливовою виявилась визначальна ідея моралі Роте, яку він розкриває в трьох складових: благо, доброчесність і обов'язок. При цьому з-поміж складових ідей моралі особливу увагу він приділяє викладу обов'язків. Зокрема, Р. Роте з'ясовує сутність обов'язку взагалі, його відношення до морального закону, ретельно описує індивідуальні й соціальні обов'язки християнина.

У другій половині XIX ст. на теренах морального богослов'я користувались великим попитом книги німецького протестантського богослова А. Еттінгена "Моральна статистика" і "Християнська моральність". При розгляді етики А. Еттінгена використані переклади фрагментів вищезазначених книг, зроблені богословом М. Зайцевим [див.: 30 та 31]. Новації, висунуті автором в цих книгах, значно вплинули на становлення теїстичної етики київських академістів. Йдеться насамперед про декларовану і належним чином обґрунтовану А. Еттінгеном концепцію "соціальної етики", згідно з якою етику доцільно розглядати крізь призму ії соціального характеру. Новації А. Еттінгена виявляються і щодо використаних ним певних методів. Так, визначальним методом його "Моральної статистики" був індуктивний, а в "Християнській моральності" переважав дедуктивний виклад матеріалу. До речі, А. Еттінген виявився прибічником саме богословської етики. До того ж в структурному відношенні він включає етику разом з догматикою до царини так званого систематичного богослов'я.

Та зрештою, А. Еттінген в своїй "Християнській моральності" провів блискучий аналіз структурної наповненості поняття моралі. Відповідно, на його думку, в понятті моралі варто вбачати три визначальні чинники, на підставі яких можна побудувати навіть самостійні етики. Мова йде про поняття доброчесності, що виявляє суб'єктивний аспект поняття моралі; обов'язку - відповідно - соціальний аспект; і величне благо, що, в свою чергу, виявляє саме універсальний аспект. При цьому А. Еттінген наголошує на формальному значенні цих понять і на необхідності поєднання їх в одній вищій ідеї. Варто додати, що ідейний доробок Еттінгена високо оцінював Маркелін Олесницький [див., напр: 13, 298-299].

Доволі самостійну морально-повчальну систему запропонував в свій час і німецький богослов Крістіан Палмер. У своїй праці "Моральність християнства" він тлумачить предмет моралі надто широко - як "життя в його виявах". До того ж предметом першої частини його системи є "природне життя", другої - "Христос" і третьої - "християнське життя". Особливу увагу при викладі своєї системи К. Палмер приділяє чотирьом чеснотам: християнській свободі, християнській любові, християнській праведності і християнській правдивості. При цьому, розкриваючи в подробицях вчення про чесноти, він ігнорує вчення про обов'язки людини. Серед академістів певного впливу з боку етики К. Палмера, зокрема тієї частини його системи моралі, де розкриваються "істини християнського життя", зазнало вчення про християнську моральність Назарія Фаворова. Варто додати також, що семінарська програма з моральнісного богослов'я за уставом 1867 року була укладена в цілковитій узгодженості з положеннями системи К. Палмера. 
3-поміж праць містичного ґатунку в середовищі академістів значним попитом користувалось творіння "Про наслідування Христа", яке приписують Фомі Кемпійському (переклад російською з'явився у 1799 році). 3 трепетністю, натхненням, релігійною щирістю, просто й невимушено оповідає автор цього твору про велич Безкінечного, Божественного і про ницість, мізерність людини в цьому світі. Людині тільки й залишається, що виявляти смиренність, послух і благоговіння перед Божественним. Саме ці якості проголошуються автором "вищими чеснотами". Моралізаторський дух книги особливо виявляється в стислих реченнях на кшталт: "Я бажаю відчути покаяння, аніж його визначити" тощо. Варто додати, що "Про наслідування Христу" й донині вважається кращою морально-повчальною книгою в католицькому світі.

Висновок. Узагальнюючи, доцільно висловити основоположну тезу. Її зміст: етична доктрина мислителів Київської духовної академії - так звана теїстична етика - актуалізується, з одного боку, завдяки творчій переробці ідейних здобутків патристики, а з іншого - концептів практичної фрілософрії німецького ідеалізму. При цьому важливим видається з'ясування особливостей сприйняття й осмислення двох, на перший погляд, відмінних у своїй сутності культурологічних традицій. Звернімо увагу, що ідеї німецької фрілософрії були вибірково критично, тобто творчо, перенесені на ґрунт духовно-академічного філософрування.

У процесі творчої переробки ідейного потенціалу німецької класики в духовно-академічній думці визначальним був, $є$ і залишається елемент віри, що не пасував перед будь-якими раціоналізованими за духом формами. Саме цей фрідеїстичний елемент, виплеканий традицією православності як логічного наслідку феномена патристики, виявився рушієм, іманентним компонентом творчого процесу взаємодії двох культур. У зв'язку з цим своєрідною квінтесенцією постає приведена в статті В. Малахова "Руська духовність і німецька вченість" [62] визначальна ідея про вченість і віру. А саме: німецька думка розвивається і поширюється в руслі концепту вченості, водночас вітчизняна розгортається у процесі поєднання концептів вченості і віри. Звідси - концепт віри постає осередком випробування ідей різноманітних культурних традицій.

\section{СПИСОК ВИКОРИСТАНИХ ДЖЕРЕЛ}

1. Амвросий, еп. Медиоланский. Об обязанностях священнослужителей, творение св. Амвросия, еп. Медиоланского / Амвросий, еп. Медиоланский // Пер. с лат. - Репринт. изд. - Москва-Рига: Благовест, 1995. - 380с.

2. Бронзов А. А. Нравственное богословие в России в течение XIX столетия / А. А. Бронзов // Христианское чтение. - 1901. - № 4. - С. 516-562.

3. Гренков А. И. Главные направления немецкого богословия в XIX В. Вып. 1. От Шлейермахера до Штрауса / А. И. Гренков // Казань, тип. Императорского Университета. - 1882. - 248 с.

4. Гренков А. И. Первоначальное происхождение науки о христианском нравоучении и краткая ее история / А. И. Гренков // Православный Собеседник. Казань. - 1875. - Часть 1. - С. 349-433.

5. Дробницкий О. Г. Понятие морали. Историко-критический очерк / О. Г. Дробницкий // М. - 1974. - 388 с.

6. Зайцев Н. О социальной этике, основанной на нравственной статистике, и о значении последней для Нравственного богословия / Из сочинения Эттингена / Н. О. Зайцев // Труды Киевской Духовной Академии. - 1871. - № 10. - С. 40-106.

7. Зайцев Н. Реализм в области наук о духе и в особенности о нравственности (из сочинения Эттингена) / Н. Зайцев // Труды Киевской Духовной Академии. - 1870. - № 12. - С. 610-644.

8. Кант И. Из "Лекций по этике" (1780-1782) / И. Кант // Этическая мысль: Научно-публицистические чтения. - М.: Политиздат, 1990. - С. 297-322.
9. Кант И. Сочинения в шести томах / И. Кант // М.: Мысль, 1965. Т.4. - Часть 1. - 544 с.

10. Малахов В. Русская духовность и немецкая ученость / В. Малахов // Вопросы философии. - 1993 - № 5. - С. 111-114.

11. Мартенсен Г. Христианское учение о нравственности / Г. Мартенсен // Пер с англ. - Т. 2. - Части 1-2. СПб. - тип. Тузова, 1890. - 816 с.

12. Олесницкий М. Из системы Нравственного богословия. Введение в науку / М. Олесницкий // Труды Киевской Духовной Академии. - 1888. - № 2. - С. 163-205.

13. Олесницкий М. Христианская ифика как наука / М. Олесницкий // Труды Киевской Духовной Академии. -1879. - № 1. - С. 68-126; №3. С. 281-331; № 6. - С. 133-182.

14. Флоровский Г., прот. Пути русского богословия / Г. Флоровский // 3-е изд., репринт. - К.: Христианско-благотворительная ассоциация "Путь к истине". - 1991. - 599 [1] с.

15. Хабермас Ю. Демократия. Разум / Ю. Хабермас // Нравственность: Московские лекции и интервью. - М.- АО "КАМІ", Изд-во: Центр Academia, 1995. -245 c.

16. Ястребов М. Новая точка зрения в системе Нравственного Богословия / М. Ястребов // Труды Киевской Духовной Академии. - 1897. № 11. - С. 367-399; 1898. - № 4. - С. 498-455.

17. Rothe R.Theologiche Ethik. 2 Aufl.-Wittenberg. - 1867. - 1 Bd.-XXVI, 407 p.

18. Wuttke A. Handbuch der cristlichen Sittenlehre. 2 Aufl. - Berlin, Erster Band, 1864. $-578 \mathrm{p}$.

\section{REFERENCES}

1. Amvrosij, ep. Mediolanskij (1995). Ob objazannostjah svjashhennosluzhitelej, tvorenie sv. Amvrosija, ep. Mediolanskogo. [On the duties of the clergy, the creation of St. Ambrose, the bishop. Mediolansky]. Moskow-Riga, Blagovest.

2. Bronzov, A. A. (1901). Nravstvennoe bogoslovie $v$ Rossii $v$ techenii XIX stoletija [Moral Theology in Russia during the Nineteenth Century]. Hristianskoe chtenie, 4, 516-562.

3. Grenkov, A. I. (1882). Glavnye napravlenija nemeckogo bogoslovija v $X I X$ v. Vyp. 1. Ot Shlejermahera do Shtrausa [The main directions of German theology in the nineteenth century. Issue. 1. From Schleiermacher to Strauss]. Kazan', tip. Imperatorskogo Universiteta.

4. Grenkov, A. I. (1875). Pervonachal'noe proishozhdenie nauki o hristianskom nravouchenii i kratkaja ee istorija [The original origin of the science of Christian moralizing and its brief history]. Pravoslavnyj Sobesednik. Kazan', Chast' 1, 349-433.

5. Drobnickij, O. G. (1974). Ponjatie morali. Istoriko-kriticheskij ocherk [The notion of morality. Historical Critical Essay]. Moskow, Nauka.

6. Zajcev, N. (1871). O social'noj jetike, osnovannoj na nravstvennoj statistike, i o znachenii poslednej dlja Nravstvennogo bogoslovija / Iz sochinenija Jettingena [On social ethics based on moral statistics, and on the significance of the latter for moral theology / From the work of Ettingen]. Trudy Kievskoj Duhovnoj Akademii, 10, 40-106.

7. Zajcev, N. (1870). Realizm v oblasti nauk o duhe i v osobennosti o nravstvennosti / Iz sochinenija Jettingena [Realism in the field of the sciences of the spirit and, in particular, about morality (from the work of Ettingen]. Trudy Kievskoj Duhovnoj Akademii, 12, 610-644.

8. Kant, I. (1990). Iz "Lekcij po jetike" (1780-1782) [From the "Lectures on Ethics" (1780-1782)]. Moskow, Politizdat.

9. Kant, I. (1965). Sochinenija v shesti tomah [Works in six volumes]. In Vol.4, Part 1. Moskow, Mysl'.

10. Malahov, V. (1993). Russkaja duhovnost' i nemeckaja uchenost' [Russian Spirituality and German Scholarship]. Voprosy filosofii, 5, 111-114.

11. Martensen, G. (1890). Hristianskoe uchenie o nravstvennosti [Christian doctrine of morality]. In Vol.2, Part 1-2. SPb., tip. Tuzova.

12. Olesnickij, M. (1888). Iz sistemy Nravstvennogo bogoslovija. Vvedenie $v$ nauku [From the system of moral theology. Introduction to Science]. Trudy Kievskoj Duhovnoj Akademii, 2, 163-205.

13. Olesnickij, M. (1879). Hristianskaja ifika kak nauka [Christian ifiq as a science]. Trudy Kievskoj Duhovnoj Akademii, 1, 68-126; , 281-331; 6, 133-182.

14. Florovskij, G. prot. (1991). Puti russkogo bogoslovija Mays of Russian theology]. Kiev, Hristiansko-blagotvoritel'naja associacija "Put' k istine".

15. Habermas, Ju. (1995). Demokratija. Razum [Democracy. Mind]. In Nravstvennost': Moskovskie lekcii i interv'ju [Morality: Moscow lectures and interviews]. Moskow, Izd-vo: Centr Academia.

16. Jastrebov, M. (1897). Novaja tochka zrenija v sisteme Nravstvennogo Bogoslovija [A new point of view in the system of moral theology]. Trudy Kievskoj Duhovnoj Akademii, 11, 367-399; (1898), 4, 498-455.

17. Rothe, R. (1867). Theologiche Ethik. 2 Aufl. Wittenberg.

18. Wuttke, A. (1864). Handbuch der cristlichen Sittenlehre. 2 Aufl. Berlin, Erster Band.

Надійшла до редколегії 05.10.17

И. В. Кондратьева, д-р филос. наук, доц.

Киевский национальный университет имени Тараса Шевченко ул. Владимирская, 60, г. Киев, 01033, Украина

\section{ИДЕЙНЫЕ ИСТОКИ ЭТИЧЕСКОЙ ДОКТРИНЫ КИЕВСКИХ АКАДЕМИСТОВ}

В статье осуществлен анализ истоков этической доктрины киевских академистов второй половины XIX - начала XX вв. Актуальность темы обусловлена необходимостью понять этическую наполненность духовно-академического философствования Киевской школы, внести определенные коррективы в методологию отечественных историко-философских исследований. Этическая 
наполненность религиозно-нравственных поисков киевских академистов заключалась в своеобразном видении и толковании проблем добродетелей, обязанности и идеи блага. Идейными истоками этических идей мыслителей Киевской духовной академии являются произведения отиов иеркви в византийской интерпретации, с одной стороны, а с другой - моральная философия Канта, Фихте и других немецких философов этического толка.

Ключевые слова: теистическая этика, моральная философия, нравственность, богословские добродетели, нравственный идеал, благо.

I. V. Kondratyeva, Doctor of Philosophical Science, Assosiate Professor

Taras Shevchenko National University of Kyiv

60, Volodymyrska Street, Kyiv, 01033, Ukraine

\section{THE CONCEPT GENESIS OF THE ETHICAL DOCTRINES OF KIEV ACADEMISTS}

The article reveals the reasons for the Kyiv thinkers to emphasize their ethical issues in their creative intelligence. Most of all there was need for justification in the light of the moral postulates of metaphysical epistemological and eschatological developments, an updated tendency towards the injection of ethics in philosophical concepts which is characteristic to the development of European thought of the second half of the nineteenth century, needs of social practice, distribution of nihilistic ideas in society.

The process of forming the ethical academic doctrine cannot be conceived without solving the problem of ideological influences. The following processes are recognized by: a) Mainly but not exclusively the Eastern-Byzantine tradition which was a logical extension of holy teachings; b) Influence of Kant's moral philosophy and in part Fichte's and theist-oriented theories of German thinkers of the nineteenth century.

The ideas of the moral-educational character contained in the works of the holy fathers and teachers of the church, in particular Athanasius the Great, John Chrysostom, John Climacus, Ambrose of Mediolans, who are subsequently influenced the formation of the ethical doctrine of the Kyiv thinkers. The ideological discrepancy between spiritual philosophers and their predecessors - professors of the Kyiv-Mohyla Academy, who came out in their intelligence from the provisions of Aristotelian ethics, is emphasized. Reasons of the influence of German idealism were found in particular practical philosophy on the process of formation of ethical attitudes of Kyiv academicians. Separately the most influential researchers of the idea of the moral philosophy of Kant and the principle of morality a priori are considered. In order to identify possible recipes of theistic concepts of German thinkers the main propositions of the theologies of morality explained by A. Richel, F. Schleiermacher, H. Martensen, A. Wutke, R. Root, A. Ettingen, K. Palmer. Actually the ethical doctrine of the thinkers of the Kiev Theological Academy is actualized on the one hand through the creative processing of the ideological achievements of patristics, on the other hand the concepts of the practical philosophy of German idealism.

Key words: theistic ethics, moral philosophy, morality, theological virtues, moral ideal, good.

УдК 130.2:[7.035.7:7.045](4)

Н. Ю. Кривда, д-р філос. наук, проф. Київський національний університет імені Тараса Шевченка вул. Володимирська, 60, м. Київ, 01033, Україна n.kryvda@britishmba.in.ua

\section{КОНСТРУЮВАННЯ УКРАÏНСЬКОЇ ІДЕНТИЧНОСТІ: ВИКЛИКИ КОМЕМОРАЦІї}

У статmі здіснюється культурософський аналіз концепції національної ідентичності у контексті "винайдення традиції". Під час формування колективної ідентичності маємо підстави вважати, що "винайдення" відповідної часу традиції є одним із головних засобів подолання стереотипів і практик, які вважаються застарілими і не відповідають покладеній на них фуункції - консолідації суспільства. Ідеї, символи та "місця пам'яті", які отримують нове змістовне наповнення, сприяють руйнуванню тих соціальних моделей, які підтримувались старою традицією, руйнуючи її саму. Саме тому у процесі конструювання традиції пери за все береться до уваги те, що суголосне сучасності, актуалізується нею і відповідає поставленим політичним цілям, натомість "забувається" те, що перешкоджає їх досягненню. У даному контексті важливого значення набуває поняття комеморації, що виступає як дієвий інструмент формування колективної ідентичності та засіб консервації історічної пам'яті.

Ключові слова: ідентичність, колективна пам'ять, історична пам'ять, комеморація, консолідація, традиція, культура.

Постановка проблеми. Після здобуття Україною незалежності актуалізується питання створення цілеспрямованої символічної політики, яка б змогла знівелювати різновекторні геополітичні та цивілізаційні орієнтації українського суспільства, забезпечивши тим самим територіальну цілісність України, шляхом свідомого конструювання новітньої української ідентичності. Попри це українська політична еліта продовжує впроваджувати сформовані в радянський період практики, спрямовані на пошук та захист від "Чужого", яким у сучасному українському соціумі став не тільки зовнішній, а й внутрішній "Інший", що призвело як до "цивілізаційного розколу" (С. Хантінгтон) українського суспільства, так і мілітарної кризи. Тому надзвичайно важливим постає той фракт, що національна ідентичність мала б вибудовуватися на принципах громадянства, пом'якшуючи етнічні, расові, мовні, культурні, релігійні та інші відмінності, шляхом впровадження аксіологічної та символічної сіток, які б змогли отримати резонанс у поліетнічному українському соціумі. Аналіз загальнонаціональної ідентичності дає змогу з'ясувати сутність сконструйованого характеру, у процесі фрормування якої ключову роль відіграють "місця пам'яті" та стратегії комеморації.

Аналіз досліджень і публікацій. До аналізу проблематики національної ідентичності та комеморації звертались наступні науковці: 3. Бауман, Е. Гобсбаум, Дж. Елів, Д. Лангевіше, М. Маколі, А. Мегілл, П. Нора, Дж. Пламенац, Т. Ренджер, Є. Романовська, Е. Сміт, Р. Суді, М. Фуше, С. Хантінгтон, П. Штомпка.
Серед українських дослідників проблематику національної ідентичності та комеморації розглядали О.Гнатюк, О. Гринів, В. Грицай, М. Жулинський, Г. Корж, В. Кравченко, В. Кремень, Л. Лазурко, Ф. Медвідь, М. Ніколко, О. Охрімчук, В. Піскун, Т. Потапчук, Ю. Рубан, В. Сергійчук, Є. Сверстюк, І. Юхновський, В. Яворівський.

Мета статті. Визначити основоположні засади національної ідентичності у її тісному взаємозв'язку 3 традицією та історичною пам'яттю, а також сфрормувати уявлення про комеморацію як дієвий інструмент для формування колективної ідентичності.

Виклад основного матеріалу дослідження. Складність історичних викликів, що постали перед Україною "тепер і зараз", змушують з напруженим інтересом придивлятися до змісту, функцій, а головне - трансформацій колективної пам'яті українців. Можна констатувати тенденцію до вихолощення радянського історичного/культурного наративу, з іншого боку, помітна інтенсифікація альтернативних пошуків, що характеризуються творенням "коротких" наративів, увічненням недавніх подій.

Декомунізація соціокультурного буття супроводжується пожвавленням інтересу до культурної спадщини та історичного минулого спільноти як засобів консолідації суспільства. Тлом консолідації певний час була ідея "національного відродження" спільноти, яка сформувалася на початку XX ст. і, власне, не утрималась на політичній арені не стільки через політичне безсилля, скільки через руйнівний вплив тоталітарної радянської 